\title{
The Effectiveness of The Use Of “Mojigoigo!" Flash-Based Learning Media Towards The Results Of The Jlpt-Like
}

\author{
Kadek Eva Krishna Adnyani ${ }^{*}$, I Wayan Sadyana², Gede Satya Hermawan ${ }^{3}$
}

1,2 Universitas Pendidikan Ganesha

A R T I C L E I N F O

Article history:

Received 20 July 2018

Received in revised

form

10 August 2018

Accepted 15 October

2018

Available online 28

November 2018

Keywords:

effectiveness, learning media, MojiGoiGo media, $J L P T$

\begin{abstract}
A B S T R A C T
The research aimed to know the effectiveness of the use of "Mojigoigo!" flash-based learning media towards the results of the JLPTLike of the second-semester students majoring in Japanese Language Education of Ganesha Education University. The method used in the study was the experimental research method with the Pre-Experimental Design and the form used was One Group Pretest - Posttest Design. The instruments used were pre-test and post-test in the form of multiple choice questions which the material was equivalent of JLPT (JLPTLike). The data analysis employed the t-test analysis. On the results of ttest, it retrieved (the value of sig. $=0.006<0.05$ ), meaning that on the statistical hypothesis $\mathrm{Ho}$ is rejected and the $\mathrm{Ha}$ is accepted, stating that "there is a significant difference between the average value of the pretest from the average value of the post-test". It shows that the use of "Mojigoigo!"flash-based learning media is proved to be effective in improving the results of the JLPT-Like of the second-semester students majoring in Japanese Language Education of Ganesha Education University.
\end{abstract}

\section{Introduction}

Learning media is anything that can communicate and transmit messages from sources in a program so that a conducive learning environment is created where the learners can join learning process effectively and efficiently. Learning media has an important role in the process of teaching and learning activities. There are several goals of using learning media including: a. Facilitating the teaching-learning process, b. Improving the efficiency of the teaching-learning, c. Maintaining relevance to the learning objectives, d. Helping students to keep concentration (Susilana, 2007).

Today, mobile-based learning media has been known. The term of mobile learning (m-learning) is a method that uses the technology of wireless moving device to the learning process by using wireless technology and mobile devices and moving device for example, PDA (Personal Digital Assistants), cell phone, and PC tablet (Sugiar: 2003). Mobile Learning is a part of the e-learning so that it is also part of distance learning (d-learning). When compared to other learning model, the mobile learning has its advantages, as follows: a.Can be used anywhere and anytime, b. Most of moving devices are relatively cheaper than the PC desktop, c. The size of devices is small so it is lighter than the PC desktop, d. It may include more learners since mobile learning utilizes the technologies associated with everyday life. (Torstein, 2005)

In the learning process, mobile-based learning media can help educators in delivering the lesson so that the material can be easily accepted by learners. Furthermore, in the last decade, the percentage of the use of electronic tools in everyday life is increasing among young people in particular the use of Gadget (phone cell, tablet, note), can simplify the learning process so that it can create the ambiance of an interesting learning into the classroom and it is much more effective than printed media. Mobile devices can be used anytime, and the use is more efficient and lighter when taken anywhere by language learners. 
In the first year of research, flash-based media called "MojiGoiGo!" application has been developed as a learning media, to test Japanese language proficiency of level 4. The first year of research employed the development model of Hannafin and Peck. There were three phases of development, namely, needs analysis phase, the design phase, the development and implementation phases. In the need analysis phase, questionnaires were used and given to the second-semester students majoring in Japanese Language Education. In the design phase, the material and the product design were created and then they were inputted into the software. In the development and implementation phase, learning media validation was done by 2 experts. Then it was proceed with individual trials involving 3 students as well as small group trial involving 9 students ( 3 people of high ability, 3 people of medium ability, and 3 people of low ability). The data was then analyzed through qualitative descriptive analysis as well as quantitative descriptive analysis. The validation results of the experts pointed out that the media is rated to be very good, the results of the individual test validation indicated that the media is rated to be very good, and the results of the small group validation test showed that the media is rated to be good and very good ( (Adnyani et.al, 2017).

The second year of research investigated the effectiveness of the use of "Mojigoigo!" flash-based learning media towards the results of the JLPT-Like of the second-semester students majoring in Japanese Language Education of Ganesha Education University. The goodness of the research is that the application that has been created will be tried out and proved its effectiveness in supporting the Japanese language learning, particularly in preparing the test for Japanese language ability. The research result is also expected to be useful as a reference in the study of experimental research on the use of learning media.

Research on the effectiveness of the use of learning media has already been conducted before, but it was conducted for the different learning media and different settings. Gon and Rawekar (2017) find out the effectiveness of Whatsapp in conveying knowledge to the MBBS students of semester 4. The research concluded that the constant existence of a facilitator and the ease to learn anytime and anywhere has made Whatsapp as a new and practical tool for teaching and learning activities. However, considering the results of the post-test, there is no significant difference between the knowledge acquisitions through Whatsapp compared with the knowledge acquisition through lecture method.

Hamad (2015) analyzed the effectiveness of the use of Adobe Flash Professional CS5.5 based learning media towards the learning outcome and response of six graders in the subject of Technology in public schools in Nablus. The research results showed a significant difference in the learning outcome and response between students who use Adobe Flash-based media and those who do not. Students who use Adobe Flash-based media get better learning outcome and give more positive responses.

Sugiar (2013) found out the effectiveness of the use for students' ability in mastering the material of Choukai (listening to the Japanese language) in the Department of Japanese Language Education of UPI in the academic year of $2013 / 2014$. The research results showed that the use of the note writing and arranging technique bring significant difference of learning outcome. Based on the results of the questionnaire, it is recognized that note writing and arranging technique create learning becomes more interesting.

In line with the background the problem can be formulated as follows: How is the effectiveness of the use of "Mojigoigo!" flash-based learning media towards the results of the JLPT-Like of the secondsemester students majoring in Japanese Language Education of Ganesha Education University.

\section{Method}

The method used in the research was experimental research method through quasi experimental design with One Group Pretest-Posttest Design. The instruments used were the test in the form of multiple choice questions which the material is equivalent to JLPT (JLPT-Like). The data analysis employed the t-test.

The research subject was the sample of second-semester students of Ganesha Education University in the total number of 10 people. The research employed a class as the research object. There is only one group serving as the control group (before the treatment was given) and the experiment group (after the treatment was given). The type of research was chosen because it is not possible to obtain control group (one class). The data that was obtained before the treatment either test results or other data was classified as the data from the control group, while the data collected after the treatment is classified as data from the experimental group. Data from the control group is often referred to as the initial tests (pretest) and experimental group data is termed the ultimate test (posttest).

Once the material was studied, the test was conducted with the material in accordance with the JLPT (JLPT-Like) to find out students' learning outcome. To analyze the data, Statistical Package for the 
Social Sciences was employed (hereafter referred to by SPSS) version 16.0. Analysis technique being used is the t-test.

The study did not employ a comparison class but already have used early tests so that the effectiveness of the use of MojiGoiGo application can be understood definitely. Subjects of research in advance were given the initial tests (pre-test) to find out the extent to which students' ability before the treatment was given. After the initial test, then the students were given the treatment, i.e. lesson of Nouryoku Shiken Level 4 (N4) through the application. Furthermore, students were given the late tests (post-test) to find out the effectiveness of the use of "Mojigoigo!" flash-based learning media towards the results of the JLPT-Like.

Simply, the research design can be described as follows:

$$
01------X \text {------- } 02
$$

Notes:

01 : pre-test

02 : post-test

$\mathrm{X}$ : Treatment (lesson of Nouryoku Shiken Level 4 through MojiGoiGo! application)

The research employed a class as the research object. There was only one group serving as the control group (before the treatment was given) and the experiment group (after the treatment was given). The type of research was chosen because it is not possible to obtain control group (one class). The data that was obtained before the treatment either test results or other data was classified as data from the control group, while the data collected after the treatment is classified as data from the experimental group. Data from the control group is often referred to as the initial tests (pretest) and experimental group data is termed the ultimate test (posttest).

Research variables consist of independent and dependent variables. Independent variables are the variables that influence, while the dependent variables are the variables that are influenced. Here are the independent and dependent variables in the study.

a) Independent variable is the use of "Mojigoigo" flash-based learning media towards the results of the

JLPT-Like of the second-semester students majoring in Japanese Language Education of Ganesha Education University

b) Dependent variable is the learning outcome of JLPT-Like of the second-semester students majoring in Japanese Language Education of Ganesha Education University.

The t-test was employed to find out the difference between the average value before the given treatment (pre-test) and average value after the given treatment (post-test) through the MojiGoiGo application. The hypotheses are:

Ho: there is no significant difference between the average value of pre-test with the average value of post-test

Ha: there is a significant difference between the average value of pre-test with the average value of post-test.

\section{Results and Discussion}

In this stage, the obtained data was analyzed by using statistical methods. The data analysis was to find out whether the hypotheses were proved or not. The data analysis stage was started by doing analysis on the results of pretest and posttest. Before the t-test was conducted, normality and homogeneity tests were needed. The tests were as follows:

\section{Normality Test}

Normality test was used to determine whether the data obtained is Gaussian or not.

Table 1. Results of Normality Test of Pre-test and Post test Data using SPSS 16.0

\begin{tabular}{ccccccc}
\hline MP & \multicolumn{3}{c}{ Kolmogorov-Smirnova $^{\mathrm{a}}$} & \multicolumn{3}{c}{ Shapiro-Wilk } \\
& Statistic & $\mathrm{df}$ & Sig & Statistic & df & Sig \\
\hline HB 1 & .161 & 10 & .200 & .915 & 10 & .318 \\
2 & .141 & 10 & .200 & .980 & 10 & .966 \\
\hline
\end{tabular}

a. Lilliefors Significance Correction

*. This is a lower bound of the true significance 
To know the data is Gaussian or not, it can be seen from the value of the significance or value of probability. If the value of significance $<0.05$, then the data is not normal and vice versa if the value significance $>0.05$, then the data is said to be normal. Based on the Kolmogorov-Smirnov test of (the value of sig. pretest $=0,318>0,05$ ) and (value sig. posttest $=0,966>0,05$ ) then the data can be said to be Gaussian.

\section{Homogeneity Test}

Homogeneity test is intended to provide certainty that the set of data that is manipulated in a series of analyses was indeed stemming from the population that is not much different (done to see the samples come from the homogeneous variant).

Table 2. Homogeneity Test Results of Data using SPSS 16.0

\begin{tabular}{ccccc}
\hline & \multicolumn{2}{c}{ Test of Homogeneity of Variance } & & Sig \\
& $\begin{array}{c}\text { Levene } \\
\text { Statistic }\end{array}$ & df1 & df2 & .599 \\
\hline HB Based on Mean & .286 & 1 & 18 & .605 \\
Based on Median & .278 & 1 & 18 & .606 \\
Based on Median and with & .278 & 1 & 15,757 & .599 \\
adjusted df & & 1 & 18 & \\
Based on trimmed mean & .286 & & & \\
\hline
\end{tabular}

To know whether the data is homogeneous or not, then it can be seen from the value of the significance or value of probability. If the value of significance $<0,05$, then the variance of the data is not homogeneous and vice versa if the value significance $>0,05$, then the variance of the data is homogeneous. Because (the value of sig.mean $=0,599>0,05$ ), (the value of sig.median $=0,605>0,05$ ), (the value of sig. median and with adjusted $\mathrm{df}=0,606>0.05$ ), and (the value of sig.trimmed mean $=0,599>0,05$ ), then the variance of the data can be said to be homogeneous.

\section{T-Test}

The test is used to find out the difference between the average value before the given treatment (pre-test) and the average value after the given treatment (post-test) through the MojiGoiGo application!

Table 3. T-Test Result of Learning Outcome using SPSS 16.0

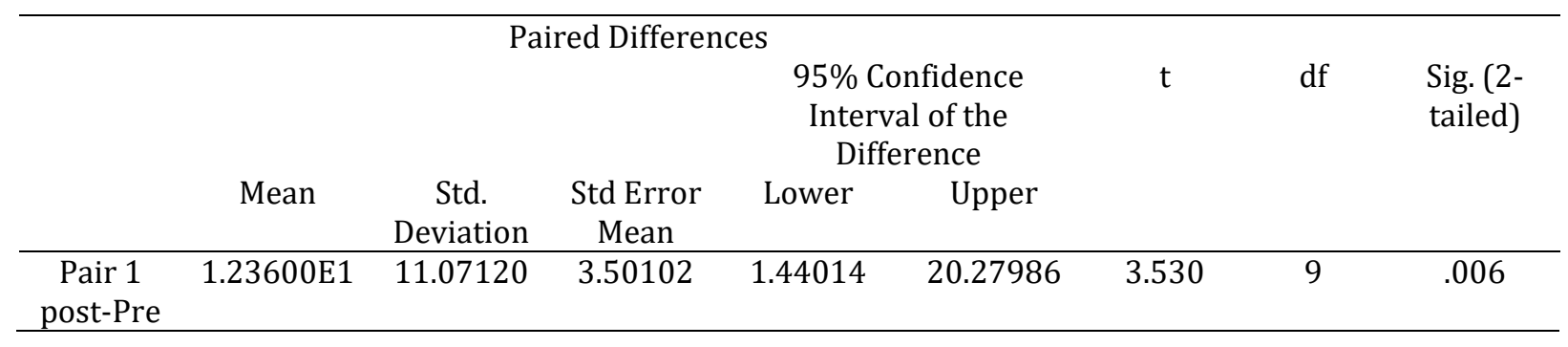

If the value of significance is $<0.05$, then $<$ Ho is rejected and vice versa if the value of significance is $\geq 0.05$, then Ho is accepted. Because (the value of sig. $=0.006<0.05$ ), then Ho is rejected and Ha is accepted so it can be concluded that there is an increase in the learning outcome of the pretest and posttest.

The analysis results of the research data show that the use of "Mojigoigo!" flash-based learning media is proved to be effective at improving the results of the JLPT-Like of the second-semester students majoring in Japanese Language Education of Ganesha Education University. The effectiveness is evidenced by the difference in the results of the pretest and the posttest. On the pretest, students' average mark was 55.26, while on the posttest, it was 63.12.

The difference of the effectiveness was also shown from the analysis results of the t-test by using a computer Program of SPSS 16.0 for Windows. On the normality test, of the Kolmogorov-Smirnov test it obtained (the value of sig. pre test $=0,318>0.05$ ) and (the value of sig. post test $=0,966>0.05$ ) then the data can be said to be Gaussian. On the test of homogeneity, (the value of sig.mean=0,599>0.05), (the value of sig.median $=0,605>0.05$ ), (the value of sig.median and with adjusted $\mathrm{df}=0,606>0.05$ ), and (the value of sig. trimmed mean=0,599>0.05), then the variance of the data is homogeneous. Lastly, on the results of the $t$ - 
test, it retrieved (the value of sig. $=0.006<0.05$ ), meaning on the statistical hypothesis Ho is rejected and the $\mathrm{Ha}$ is accepted, stating that "there is a significant difference between the average value of the pretest and that of the posttest". It indicates that the use of "Mojigoigo" flash-based learning media is proved to be effective at improving the results of the JLPT-Like of the second-semester students majoring in Japanese Language Education of Ganesha Education University.

In the learning process, mobile-based learning media can help educators in delivering the lesson so that the material can be easily accepted by learners. Furthermore, in the last decade, the percentage of the use of electronic tools in everyday life is increasing among young people in particular the use of Gadget (phone cell, tablet, note), can simplify the learning process so that it can create the ambiance of an interesting learning into the classroom and it is much more effective than printed media. Mobile devices can be used anytime, and the use is more efficient and lighter when taken anywhere by language learner, Torstein, 2005). Torstein's opinion is in line with the research results showing that "Mojigoigo!" flashbased learning media is proved to be effective at improving the results of the JLPT-Like. Therefore, the use of flash-based learning media in Japanese Language proficiency needs to be developed and effectively implemented so that the learning quality could improve.

\section{Conclusions and Suggestions}

Conclusions after conducting research on the effectiveness of the use of "Mojigoigo!" flash-based learning media towards the results of the JLPT-Like of the second-semester students majoring in Japanese Language Education of Ganesha Education University are as follows:

1. The use of "Mojigoigo!" flash-based learning media is proved to be effective at improving the results of the JLPT-Like of the second-semester students majoring in Japanese Language Education of Ganesha Education University. It is evidenced by the difference in the results of the pretest and the posttest. On the pretest, students' average mark was 55.26, while on the posttest, it was 63.12.

2. The difference of the effectiveness is also indicated from the analysis results of the t-test by using a computer Program of SPSS 16.0 for Windows. On the results of the t-test, it retrieved (the value of sig. $=0.006<0.05$ ), meaning that on the statistical hypothesis Ho is rejected and the Ha is accepted, stating that "there is a significant difference between the average value of pre-test with the average value of post-test". It indicates that the use of "Mojigoigo" flash-based learning media is proved to be effective at improving the results of the JLPT-Like of the second-semester students majoring in Japanese Language Education of Ganesha Education University.

\section{Refferences}

Cohen, Louis., Manion, Lawrence., dan Morrison, Keith. 2007. Research Methods in Education. London: Routledge.

Gon, Sonia dan Rawekar, Alka. 2017. Effectivity of E-Learning through Whatsapp as a Teaching Learning Tool. In : MVP Journal of Medical Sciences, Vol 4(1), 19-25, January-June 2017. Retrieved November 20, 2017, from: http://www.informaticsjournals.com/index.php/mvpjms/article/view/8454/13263

Hamad, Amani Asad Abdul-Azis. 2015. The Effectiveness of Adobe Flash Program on The Achievement of Sixth Graders in Technology and Their Attitudes Towards it at the Governmental Schools of Nablus City. Thesis. Nablus: An-Najah University. Retrieved November 19, 2017, from: https://scholar.najah.edu/sites/default/files/Amani\%20Asad\%20Abdul-Aziz\%20Hamad.pdf

Hikmawati, Fenti. 2017. Metodologi Penelitian. Depok: Rajagrafindo Persada.

Robso, dkk. 2003, Mobile Learning and Handled Devices in The Classroom". Eduworks Corporation, Corvallis Oregon. USA IMS. Australia.

Sugiar, Rani Hardiyanti. 2013. Efektivitas Penggunaan Metode Analisis Teks Teknik Catatan Tulis dan Susun (TS) Pada Pembelajaran Shokyu Choukai II. Bandung: Universitas Pendidikan Indonesia. $\begin{array}{llll}\text { Retrieved November } & 12, & \text { 2017, from: }\end{array}$ http://repository.upi.edu/2530/6/S_JEP_0902618_Chapter3.pdf

Sugiyono. 2009. Metode Penelitian Pendidikan: Pendekatan Kuantitatif, Kualitatif dan R\&D Bandung: Alfabeta. 
Susilana Rudi, Riyana Cepi. 2007. Media Pembelajaran Hakikat Pengembangan, Pemanfaatan dan Penilaian. Bandung : CV Wacana Prima

The Japan Foundation and Japan Educational Exchange. 2012. N1-N5 :

Summary of Linguistic Competence Required for Each Level. Didapat dari

: http://www.jlpt.jp/e/about/levelsummary.html

The Japan Foundation. 2015. Survey Report on Japanese-Language Education Abroad 2015. Retrieved November 17, 2017, from: https://www.jpf.go.jp/j/project/japanese/survey/result/dl/survey_2015/Report_all_e.pdf

Thoifah, L'anatut. 2015. Statistika Pendidikan dan Metode Penelitian Kuantitatif. Malang: Madani.

Torstein Rekkedal. 2005 Design Development and Evaluation of Mobile Learning. NKI Distance Education. NKI Forlaget... 